\title{
Trafność teoretyczna Kwestionariusza radzenia sobie $w$ sytuacjach stresowych CISS ze szczególnym uwzględnieniem trafności teore- tycznej skali stylu skoncentrowanego na unikaniu
}

\author{
Agata Jabłońska ${ }^{1}$ \\ ajablonska.pl@gmail.com \\ Szkoła Wyższa Psychologii Społecznej \\ Wydziat Zamiejscowy we Wrocławiu
}

\begin{abstract}
Sprawdzono trafność teoretyczną Kwestionariusza radzenia sobie w sytuacjach stresowych (CISS) ze szczególnym uwzględnieniem trafności skali stylu skoncentrowanego na unikaniu (SSU). 141 studentów (76 kobiet, 65 mężczyzn) w wieku 19-26 lat, wypełniło: kwestionariusz CISS, Skalę Uogólnionej Własnej Skuteczności (GSES), Pure Procrastination Scale (PPS) oraz Kwestionariusz spędzania wolnego czasu (KWC). Badanie trafności metodą analiz: macierzy korelacji, czynnikowej oraz struktury wewnętrznej testu, dostarczyło argumentów świadczących na korzyść trafności teoretycznej, zarówno skali SSU jak i całego kwestionariusza. Stwierdzono różnice w zakresie kierunku związku między poczuciem własnej skuteczności (GSES) i poszukiwaniem kontaktów towarzyskich (PKT) w zależności od płci badanych. Im wyższe poczucie własnej skuteczności miały kobiety, tym chętniej angażowały się w poszukiwanie kontaktów towarzyskich. Współzależność ta wykazała ujemny kierunek w grupie mężczyzn. Uwzględniając uzyskane dane oraz wyniki badań zagranicznych (Endler, Parker, 1990b, 1994; Cosway, Endler, Sadler, Deary, 2000), sugeruje się rozważenie wprowadzenia w polskiej wersji kwestionariusza zróżnicowania norm stenowych dla płci.
\end{abstract}

\section{Wprowadzenie teoretyczne}

Kwestionariusz radzenia sobie w sytuacjach stresowych (CISS; Endler, Parker, 1990a) jest najczęściej stosowanym w Polsce testem służącym do diagnozy sposobów radzenia sobie ze stresem (Heszen, 2013). Krajowej adaptacji narzędzia dokonał Szczepaniak, Strelau i Wrześniewski w 1996 r. Zarówno polska, jak i oryginalna wersja kwestionariusza, charakte-

\footnotetext{
${ }^{1}$ Raport z badania został napisany na podstawie pracy magisterskiej pt. „Trafność teoretyczna Kwestionariusza radzenia sobie $w$ sytuacjach stresowych CISS ze szczególnym uwzględnieniem trafności teoretycznej skali stylu skoncentrowanego na unikaniu", napisanej w Szkole Wyższej Psychologii Społecznej pod kierunkiem prof. dr hab. Elżbiety Hornowskiej i recenzowanej przez dr. Tomasza Czuba.
} 
ryzują się dobrymi właściwościami psychometrycznymi i rekomendowane są jako trafne i rzetelne narzędzia do pomiaru stylów radzenia sobie ze stresem (Strelau, Jaworowska, Wrześniewski, Szczepaniak, 2005).

Rzetelność polskiej wersji testu określano badaniem stabilności bezwzględnej oraz zgodności wewnętrznej skal. Stabilność bezwzględną skal ustalano na podstawie badań przeprowadzonych w grupie 98 uczniów klas licealnych. Badani wypełniali kwestionariusz dwukrotnie - w odstępie 2-3 tygodni. Współczynniki korelacji między pomiarami wyniosły dla skal: stylu skoncentrowanego na zadaniu (SSZ) $r=0,75$, stylu skoncentrowanego na emocjach (SSE) $r=0,78$, stylu skoncentrowanego na unikaniu (SSU) $r=0,80$, dla podskal: angażowania się w czynności zastępcze (ACZ) $r=0,79$ i poszukiwania kontaktów towarzyskich (PKT) $r=0,73$.

Zgodność wewnętrzna skal CISS oceniona została w badaniu, w którym wzięły udział trzy grupy osób: 316 studentów, 252 mężczyzn po zawale serca oraz 1006 uczniów ze szkół średnich i zawodowych. Obliczenia przeprowadzono oddzielnie dla każdej z grup. Dla skal SSZ i SSE otrzymano wartości współczynnika $\alpha$-Cronbacha w granicach od 0,82 do 0,88 , natomiast dla skali SSU wartości wahały się od 0,74 do 0,78. Podskala PKT w dwóch grupach wykazała rzetelność poniżej 0,7 (co można tłumaczyć małą liczbą pozycji w podskali). Autorzy badania wskazują, że mimo iż współczynniki zgodności wewnętrznej poszczególnych skal są nieco niższe niż w wersji oryginalnej (średnio o 0,05), należy je uznać za zadowalające (Strelau, Jaworowska, Wrześniewski, Szczepaniak, 2005).

Badania polskiej wersji CISS obejmowały czynnikowy, kryterialny oraz teoretyczny aspekt trafności. Szczególnie obszerne badania poświęcono trafności teoretycznej. W tym celu autorzy polskiej adaptacji zbadali związki CISS z narzędziami służącymi do pomiaru cech osobowości, temperamentu, lęku, inteligencji, inteligencji emocjonalnej oraz kompetencji społecznych (Szczepaniak, Strelau, Wrześniewski, 1996; Strelau, Jaworowska, Wrześniewski, Szczepaniak, 2005). Szeroko zakrojone badania pozwoliły na zarekomendowanie polskiej adaptacji kwestionariusza, jako narzędzia charakteryzującego się satysfakcjonującą trafnością (Strelau i in., 2005).

W celu ustalenia, do jakiego stopnia pozycje polskiej wersji testu są równoważne z wersją oryginalną, Szczepaniak, Strelau i Wrześniewski (1996) dokonali charakterystyki psychometrycznej pozycji. Przyjęto sześć kryteriów oceny: moc dyskryminacyjną, korelację ze skalami, wielkość ładunku czynnikowego, wierność tłumaczenia, zgodność ekspertów i aprobatę społeczną. Badania wykazały, że pięć pozycji kwestionariusza nie spełnia co najmniej dwóch z kryteriów. Są to pozycje nr: 39 (SSZ), 45 (SSE) oraz trzy itemy skali 
SSU - 3, 32 i 35. Wyeliminowanie pozycji niespełniających założonych warunków nie wpłynęło na poprawę własności psychometrycznych kwestionariusza, wobec czego pozostawiono oryginalną liczbę itemów (Szczepaniak i in., 1996).

Należy podkreślić, że charakterystyki psychometryczne polskiej i oryginalnej wersji kwestionariusza są porównywalne. Krajowa adaptacja charakteryzuje się wysoką rzetelnością oraz satysfakcjonującą trafnością kryterialną i teoretyczną. W ramach udoskonalenia narzędzia autorzy polskiej adaptacji proponują, aby dążyć do modyfikacji lub zmiany pozycji wymagających poprawy własności psychometrycznych - zwłaszcza trzech pozycji skali SSU (Szczepaniak, Strelau, Wrześniewski, 1996).

Celem prezentowanych badań własnych było sprawdzenie trafności teoretycznej kwestionariusza CISS. W celu pomiaru zbieżnego aspektu trafności testu podjęto się zbadania związków między stylami radzenia sobie ze stresem a poczuciem własnej skuteczności (mierzonym Skala Uogólnionej Własnej Skuteczności, GSES) i prokrastynacją (mierzoną Pure Procrastination Scale, PPS). Uwzględniając sugestię autorów polskiej adaptacji testu, W szczególności koncentrowano się na trafności teoretycznej skali stylu skoncentrowanego na unikaniu (SSU). Zadaniem była również poprawa psychometrycznych własności skali SSU, poprzez uzupełnienie zestawu pozycji testowych należących do skali. W tym celu skonstruowano Kwestionariusz spędzania wolnego czasu (SWC) obejmujący czynności zastępcze, które nie zostały ujęte na skali SSU.

Zjawisko prokrastynacji ${ }^{2}$ polega na tym, że jednostka zwleka z podjęciem zamierzonego działania, mimo iż spodziewa się, że z tego powodu znajdzie się w gorszej sytuacji (Steel, 2007). Istnienie związków między prokrastynacją a stylami radzenia sobie ze stresem stwierdzili Flett, Blankstein i Martin (1995). Otrzymane przez badaczy wyniki potwierdziły istnienie negatywnego związku między prokrastynacją a zadaniowym stylem radzenia sobie ze stresem. Flett i in. wykazali również, że osoby, które zwlekają z wykonywaniem zadań, częściej angażują się w emocjonalny styl radzenia sobie, a także stosują unikanie $\mathrm{w}$ formie angażowania się $\mathrm{w}$ czynności zastępcze. Na tej podstawie w badaniach własnych przyjęto, że prokrastynacja koreluje negatywnie ze stylem skoncen-

\footnotetext{
${ }^{2}$ Prokrastynacja - z łac. procrastinare - ,to put off till the morrow” (Klein, 1966), czyli „odkładać na jutro". Termin nie występuje w słowniku języka polskiego, jednak zapożyczenie jest powszechnie stosowane w mowie potocznej. Biorąc pod uwagę, że termin procrastination funkcjonuje w anglojęzycznej literaturze naukowej, zdecydowano się użyć w pracy spolszczonej formy prokrastynacja. Określenie jest tu stosowane zamiennie z terminami: zwlekanie czy odwlekanie.
} 
trowanym na zadaniu (SSZ) oraz że istnieje pozytywny związek między: prokrastynacją a stylem skoncentrowanym na emocjach (SSE) oraz prokrastynacją i angażowaniem się w czynności zastępcze (ACZ).

Poczucie własnej skuteczności ${ }^{3}$ (self-efficacy) definiowane jest jako przekonanie o tym, że prowadzenie skutecznego działania w nowych, stresujących i niejednoznacznych sytuacjach jest możliwe (Oleś, 2003). Bandura (1991) wskazuje, iż przekonanie o własnej skuteczności wiąże się z mobilizacją do działania, wkładanym w nie wysiłkiem, wytrwałością, umiejętnością radzenia sobie z przeszkodami i porażkami. Spostrzegana własna skuteczność jest sprzężona zwrotnie z zaangażowaniem w działanie (Oleś, 2003). Wobec przytoczonych informacji uzasadnione jest oczekiwanie, że przekonanie o własnej skuteczności będzie pozostawać $\mathrm{W}$ dodatnim związku $\mathrm{z}$ zadaniowym stylem radzenia sobie ze stresem (SSZ).

Poczucie własnej skuteczności reguluje zarówno zachowania unikowe jak i stan pobudzenia związany z lękiem (Bandura, 1993). Badania nad rolą lęku i przekonania o własnej skuteczności w modelu zachowań unikających wskazują na to, iż poczucie własnej skuteczności jest lepszym predyktorem zachowania niż odczuwany przez osobę lęk (Bandura, 1993). Na tej podstawie, w badaniach własnych przyjęto, że radzenie sobie ze stresem za pomocą stylu skoncentrowanego na unikaniu (SSU) będzie negatywnie związane z przekonaniem o własnej skuteczności.

W oparciu o teorię Bandury (1991, 1993, 2001) oraz wyniki badania Shikai, Uji, Chen, Hiramura, Tanaka, Shono i Kitamura (2007) założono także istnienie negatywnego związku między przekonaniem o własnej skuteczności a stylem radzenia sobie skoncentrowanym na emocjach (SSE).

Konstrukcja Kwestionariusza spędzania wolnego czasu (SWC), obejmującego czynności zastępcze nieujęte na skali SSU, pozwoliła na przyjęcie kolejnych dwóch hipotez wskazujących na istnienie pozytywnych związków między: kwestionariuszem SWC a skalą skoncentrowaną na unikaniu (SSU) oraz kwestionariuszem SWC a angażowaniem się w czynności zastępcze (ACZ).

\footnotetext{
${ }^{3}$ Za Olesiem (2003) - sformułowanie poczucie stosowane jest tu zamiennie z określeniem przekonanie o własnej skuteczności.
} 


\section{Badania własne}

\section{Metoda}

W badaniu wykorzystano: Kwestionariusz radzenia sobie $w$ sytuacjach stresowych (CISS), Kwestionariusz spędzania wolnego czasu (SWC), Skalę Uogólnionej Własnej Skuteczności (GSES) oraz skalę Pure Procrastination Scale (PPS) ${ }^{4}$.

Kwestionariusz radzenia sobie $w$ sytuacjach stresowych (CISS). CISS (Coping Inventory for Stressful Situations) autorstwa Endlera i Parkera (1990a) służy do badania stylów radzenia sobie ze stresem. Narzędzie składa się 48 stwierdzeń dotyczących emocji i zachowań ludzi na trudne, stresujące sytuacje. Zadaniem osoby badanej jest określić przy każdym stwierdzeniu częstotliwość, z jaką podejmuje dane działanie (lub odczuwa dany stan czy emocję) na skali, gdzie 1 oznacza nigdy, a 5 - bardzo często. Otrzymane wyniki prezentowane są na trzech skalach, określających style radzenia sobie ze stresem skoncentrowane na: zadaniu (SSZ), emocjach (SSE) oraz unikaniu (SSU).

- Skala Styl skoncentrowany na zadaniu (SSZ) określa radzenie sobie ze stresem polegające na aktywnym podejmowaniu próby rozwiązania problemu. Osoby uzyskujące wysokie wyniki na skali, w sytuacjach stresowych dążą do rozwiązania problemu poprzez próbę zmiany swojej sytuacji lub poznawcze przekształcenia.

- Skala Styl skoncentrowany na emocjach (SSE) dotyczy radzenia sobie ze stresem polegającego na koncentracji na własnych, negatywnych przeżyciach emocjonalnych, tj. napięcie, poczucie winy, przygnębienie czy złość.

- Skala Styl skoncentrowany na unikaniu (SSU) określa radzenie sobie ze stresem polegające na wystrzeganiu się myślenia, przeżywania emocji a także doświadczania trudnych, stresujących sytuacji. Może przyjmować dwie formy: poszukiwania kontaktów towarzyskich (podskala PKT) lub angażowania się w czynności zastępcze (podskala ACZ), tj.: kupowanie, oglądanie filmów, sen czy objadanie się.

Każda ze skal składa się z 16 pozycji. Podskale ACZ i PKT liczą kolejno: 8 i 5 pozycji. Kwestionariusz jest rekomendowany jako trafne $i$ rzetelne narzędzie służące do pomiaru stylów radzenia sobie ze stresem (Strelau, Jaworowska, Wrześniewski, Szczepaniak, 2005) (dane o rzetelności i trafności testu podano we wprowadzeniu).

\footnotetext{
${ }^{4}$ Badanie zostało przeprowadzone z wykorzystaniem legalnych wersji wymienionych narzędzi. Na użycie i przetłumaczenie Pure Procrastination Scale otrzymano zgodę autora - Piersa Steela.
} 
Kwestionariusz spędzania wolnego czasu (SWC) - narzędzie własne. ${ }^{5}$ Narzędzie powstało na potrzeby prezentowanego badania. Celem konstrukcji było stworzenie pozycji, które poszerzyłyby skalę stylu skoncentrowanego na unikaniu (SSU). Istotą procedury było utworzenie itemów dotyczących czynności zastępczych, które nie zostały uwzględnione w kwestionariuszu CISS. W tym celu wygenerowano pulę kilkunastu pozycji, które zostały poddane ewaluacji przez sześciu sędziów kompetentnych. Ich zadaniem było ocenienie W zakresie od 0 do 2, które z zamieszczonych pozycji mają zasadnicze znaczenie dla testu, a także, w przypadku kilku z nich, wybranie najlepszego sformułowania pod względem językowym. Sędziowie kompetentni dysponowali definicją stylu skoncentrowanego na unikaniu (SSU), przykładowymi czynnościami zastępczymi oraz informacją na temat celu procedury, w której biorą udział. Kryterium doboru pozycji do ostatecznej wersji skali była suma rang, które uzyskały poszczególne itemy. Ostateczna wersja narzędzia obejmowała 6 pozycji, gdzie 3 z nich dotyczyły aktywności odbywających się przez Internet, natomiast pozostałe: grania w różnego rodzaju gry, uprawiania sportu oraz picia alkoholu lub stosowania innych środków w celu poprawy samopoczucia. Ponieważ skala miała stanowić rozszerzenie SSU, logicznym następstwem było przyjęcie takiej samej instrukcji oraz zakresu odpowiedzi jak w kwestionariuszu CISS.

Skala Uogólnionej Własnej Skuteczności (GSES). Skala jest polską wersją testu Generalized Self-Efficacy Scale, opracowanego przez Schwarzera i Jerusalema w 1992 r. (Juczyński, 2009). Autorami polskiej wersji skali są: Schwarzer, Jerusalem i Juczyński (Juczyński, 2009). GSES służy do pomiaru siły ogólnego przekonania osoby do własnej skuteczności radzenia sobie w trudnych sytuacjach. Narzędzie składa się z 10 pozycji tworzących jeden czynnik. Zadaniem badanego jest zdecydować, w jakim stopniu każde ze stwierdzeń go charakteryzuje. Oceny dokonuje się na czterostopniowej skali (gdzie poszczególne punkty oznaczają: 1 - nie, 2 - raczej nie, 3 - raczej tak i 4 -tak). Suma uzyskanych punktów jest wskaźnikiem uogólnionego poczucia własnej skuteczności. Im wyższy wynik uzyskała osoba badana, tym większe jest jej poczucie własnej skuteczności (Juczyński, 2009). Zgodność wewnętrzną skali oszacowano na podstawie badania, w którym wzięło udział 174 osób. Współczynnik $\alpha$-Cronbacha wyniósł 0,85 . Spójność skali weryfikowana w grupie 85 osób 5 tygodni później (metodą test-retest) wyniosła 0,78. Wskaźniki te są podobne do uzyskanych w wersji oryginalnej kwestionariusza (Juczyński, 2009).

\footnotetext{
${ }^{5}$ Pełna wersja narzędzia dostępna u autorki badania.
} 
Pure Procrastination Scale (PPS). Skala służy do pomiaru tendencji jednostki do prokrastynacji. Narzędzie powstało w wyniku analizy czynnikowej przeprowadzonej na zsumowanych pozycjach trzech kwestionariuszy służących do pomiaru prokrastynacji (Adult Inventory of Procrastination, AIP; McCown, Johnson, 1989; Decisional Procrastination Questionnaire, DPQ; Mann, Burnett, Radford, Ford, 1997; General Procrastination Scale, GPS; Lay, 1986). Otrzymano rozwiązanie trzyczynnikowe, w którym czynnik pierwszy, drugi i trzeci wyjaśniały kolejno: 36\%, 7\% i 6\% wariancji wyników. 12 pozycji składających się na pierwszy czynnik, opisany przez Steela (2010) jako główny czynnik prokrastynacji (general procrastinating factor), utworzyło skalę PPS. Współczynnik $\alpha$-Cronbacha otrzymany dla wyekstrahowanej skali wyniósł 0,92 . Trafności teoretyczną narzędzia oceniono na podstawie analizy macierzy korelacji skali z: Satisfaction with Life Scale (SWLS; Diener, Emmons, Larsen, Griffin, 1985), Susceptibility to Temptation Scale (STS; Steel, 2002) oraz Irrational Procrastination Scale (IPS; Steel, 2002). Następnie porównano otrzymane dane ze współczynnikami korelacji wymienionych narzędzi z kwestionariuszami: AIP, DPQ i GPS. Skala Pure Procrastination Scale (PPS) uzyskała najwyższe współczynniki korelacji z narzędziami użytymi do oceny trafności, co potwierdziło aspekt zbieżny trafności teoretycznej (Steel, 2010).

Nowo utworzona skala nie została wydana jako odrębne narzędzie, co wiąże się z brakiem instrukcji oraz skali odpowiedzi. Na potrzeby przedstawianego badania, zaadaptowano instrukcję kwestionariusza GPS (Lay, 1986), z którego pochodzi część pozycji skali PPS. Wszystkie narzędzia, których wybrane pozycje utworzyły PPS, zawierają 5-stopniową skalę odpowiedzi. Wobec czego również taką formę zastosowano $\mathrm{w}$ przetłumaczonej na język polski wersji PPS (gdzie 1 oznacza zdecydowane nie, a 5 zdecydowane tak).

\section{Procedura badania}

W badaniu uczestniczyli studenci różnych wydziałów wrocławskich uczelni. Grupa liczyła łącznie 146 osób (77 kobiet i 69 mężczyzn). Wyników badania 5 osób nie brano pod uwagę w związku ze zbyt dużą ilością braków danych. W rezultacie analizowano wyniki 141 osób (76 kobiet i 65 mężczyzn),w wieku 19-26 lat $(M=21,21 ; S D=1,42)$.

Proces zbierania danych przeprowadzono w maju i czerwcu 2014 roku. Studentów do badania rekrutowano przed zajęciami. Badanie miało charakter grupowy, odbywało się przed 
rozpoczęciem zajęć w salach ćwiczeniowych i wykładowych, za zgodą prowadzącego. Uczestnicy zostali poinformowani o jego celu (praca magisterska), o metodzie (wypełnienie metryczki oraz czterech kwestionariuszy), a także o anonimowym i dobrowolnym udziale w badaniu. Arkusze rozdano po wyrażeniu świadomej zgody na uczestnictwo w procedurze. Czas wypełniania kwestionariuszy nie był ograniczony.

Analiza uzyskanych wyników miała charakter kilkuetapowy. Weryfikację hipotez przeprowadzono na podstawie analizy macierzy korelacji. Do dalszego opracowania wyników zastosowano analizę czynnikową oraz analizę struktury wewnętrznej testu. Dokonano także charakterystyki psychometrycznej pozycji kwestionariusza CISS. W celu porównania grupy kobiet i mężczyzn zastosowano test t-Studenta.

\section{Uzyskane wyniki}

W celu weryfikacji założonych hipotez obliczono korelacje $r$-Pearsona dla wyników otrzymanych na poszczególnych skalach i podskalach Kwestionariusza radzenia sobie $w$ sytuacjach stresowych (CISS) oraz wyników uzyskanych z Kwestionariusza spędzania wolnego czasu (SWC), Skali Uogólnionej Własnej Skuteczności (GSES) i Pure Procrastination Scale (PPS). Zestawienie danych przedstawiono w tabeli 1.

Tabela 1. Macierz korelacji między skalami i podskalami kwestionariusza CISS oraz kwestionariuszami: SWC, GSES i PPS ( $\mathrm{N}=141)$.

\begin{tabular}{|c|c|c|c|c|c|c|c|c|}
\hline & SSZ & SSE & SSU & $\mathrm{ACZ}$ & PKT & SWC & GSES & PPS \\
\hline SSZ & 1 & $-0,17 *$ & - & - & $0,24 * *$ & - & $0,56^{* *}$ & $-0,30 * *$ \\
\hline SSE & & 1 & $0,36^{* *}$ & $0,34 * *$ & $0,25^{* *}$ & $0,34 * *$ & $-0,51^{* *}$ & $0,45^{* *}$ \\
\hline SSU & & & 1 & $0,89 * *$ & $0,80 * *$ & $0,45^{* *}$ & - & $0,18^{*}$ \\
\hline $\mathrm{ACZ}$ & & & & 1 & $0,50 * *$ & $0,45^{* *}$ & - & $0,25 * *$ \\
\hline PKT & & & & & 1 & $0,26^{* *}$ & - & - \\
\hline SWC & & & & & & 1 & - & $0,46^{* *}$ \\
\hline GSES & & & & & & & 1 & $-0,40 * *$ \\
\hline PPS & & & & & & & & 1 \\
\hline
\end{tabular}

SSZ - styl skoncentrowany na zadaniu; SSE - styl skoncentrowany na emocjach; SSU - styl skoncentrowany na unikaniu; ACZ - angażowanie się w czynności zastępcze (podskala); PKT - poszukiwanie kontaktów towarzyskich (podskala); SWC - Kwestionariusz spędzania wolnego czasu; GSES - Skala uogólnionej własnej skuteczności; PPS - Pure Procrastination Scale. $* \mathrm{p}<0,05 ; * \mathrm{p}<0,01$.

Wyniki kwestionariusza GSES korelują wysoko: dodatnio ze skalą stylu skoncentrowanego na zadaniu (SSZ) i ujemnie zeskalą stylu skoncentrowanego na emocjach (SSE). 
Obie otrzymane zależności są zgodne z założonymi hipotezami. Nie potwierdziło się założenie o istnieniu związku między GSES a skalą stylu skoncentrowanego na unikaniu (SSU). Skala PPS koreluje umiarkowanie: ujemnie ze skalą SSZ i dodatnio ze skalą SSE. Ujawnił się także związek między skalą PPS a podskalą angażowania się w czynności zastępcze (ACZ). Oznacza to, że potwierdziły się wszystkie założone związki prokrastynacji ze stylami radzenia sobie ze stresem. Wyniki kwestionariusza SWC wykazują pozytywne, umiarkowane związki ze skalą SSU oraz podskalą ACZ, co jest zgodne z przewidywaniami.

Na podstawie otrzymanej macierzy korelacji można stwierdzić, że zdecydowana większość założonych hipotez potwierdziła się. W związku z tym uzasadnione jest stwierdzenie, że uzyskane dane dotyczące związku stylów radzenia sobie ze stresem z poczuciem własnej skuteczności, prokrastynacją i kwestionariuszem SWC, dostarczają argumentów na rzecz trafności teoretycznej kwestionariusza CISS.

Wykonanie analogicznej analizy dla badanych zmiennych, z uwzględnieniem płci osób badanych, wykazało interesujące różnice w otrzymanych wzorcach korelacji. Porównanie uzyskanych danych dla grupy kobiet i mężczyzn umieszczono w tabeli 2.

Tabela 2. Macierz korelacji między skalami i podskalami kwestionariusza CISS oraz kwestionariuszami: SWC, GSES i PPS - porównanie grupy kobiet $(n=76)$ i mężczyzn $(n=65)$.

\begin{tabular}{|c|c|c|c|c|c|c|c|c|}
\hline \multicolumn{9}{|c|}{ Kobiety / Mężczyźni } \\
\hline & SSZ & SSE & SSU & $\mathrm{ACZ}$ & PKT & SWC & GSES & PPS \\
\hline SSZ & 1 & - & $0,33 * *$ & - & $0,43 * *$ & - & $0,63 * *$ & $-0,25 *$ \\
\hline SSE & - & 1 & - & - & - & $0,36^{* *}$ & $-0,45^{* *}$ & $\mathbf{0 , 5 8} * *$ \\
\hline SSU & - & $\mathbf{0 , 4 8 * *}$ & 1 & $0,87 * *$ & $0,76^{* *}$ & $0,45^{* *}$ & $0,29 *$ & - \\
\hline $\mathrm{ACZ}$ & $-0,26 *$ & $\mathbf{0 , 3 8} * *$ & $0,86^{* *}$ & 1 & $0,40 * *$ & $0,39 * *$ & - & - \\
\hline PKT & - & $0,40 * *$ & $0,76^{* *}$ & $0,37 * *$ & 1 & $0,26 *$ & $\mathbf{0 , 3 3} * *$ & - \\
\hline SWC & - & $0,29 *$ & $0,46^{* *}$ & $0,54 * *$ & - & 1 & - & $\mathbf{0 , 3 9} * *$ \\
\hline GSES & $0,50 * *$ & $-0,57 * *$ & $-0,32 *$ & $-0,26 *$ & $-0,26 *$ & - & 1 & $-0,43 * *$ \\
\hline PPS & $-0,36^{* *}$ & $\mathbf{0 , 3 7}{ }^{\text {*** }}$ & $0,32 * *$ & $0,36^{* * *}$ & - & $\mathbf{0 , 5 6} * *$ & $-0,39 * *$ & 1 \\
\hline
\end{tabular}

Wyniki dla grupy kobiet umieszczono powyżej przekątnej, dla mężczyzn - poniżej. Nazwy skal podano $\mathrm{w}$ tabeli 1.Pogrubionym drukiem zaznaczono związki, na które warto zwrócić uwagę. Część z nich omówiono w tekście.

$* \mathrm{p}<0,05 ; * * \mathrm{p}<0,01$.

Uzyskane dane wyjaśniają przyczynę braku zakładanego związku miedzy poczuciem własnej skuteczności (GSES) a skalą stylu skoncentrowanego na unikaniu (SSU). Okazuje się, że omawiana współzależność wykazuje ujemny kierunek w grupie mężczyzn, natomiast dodatni w grupie kobiet. Nieoczekiwany związek wynika z występowania dodatniej korelacji między GSES a podskalą poszukiwania kontaktów towarzyskich (PKT). Na tej podstawie 
należy stwierdzić, że badane kobiety o wysokim poczuciu własnej skuteczności częściej radzą sobie ze stresem poprzez poszukiwanie kontaktów towarzyskich niż kobiety o niskim poczuciu własnej skuteczności. Zależność taka nie występuje w grupie mężczyzn. Im wyższe poczucie własnej skuteczności charakteryzowało badanych mężczyzn, tym rzadziej angażowali się w poszukiwanie kontaktów towarzyskich oraz stosowanie czynności zastępczych.

Warte zauważenia są również otrzymane różnice w związkach między prokrastynacją (PPS) a stylami radzenia sobie ze stresem. U badanych kobiet zwlekanie pozostaje w silnym związku ze stosowaniem stylu skoncentrowanego na emocjach (SSE) i nie wiąże się ze stylem radzenia sobie skoncentrowanym na unikaniu (SSU). U mężczyzn zwlekanie wiąże się zarówno ze stylem skoncentrowanym na emocjach (SSE) jak i stylem skoncentrowanym na unikaniu (SSU), wyrażającym się w angażowaniu się w czynności zastępcze (ACZ).

Interesujące różnice obserwuje się również w interkorelacjach skal kwestionariusza CISS. U badanych kobiet zadaniowy styl radzenia sobie ze stresem (SSZ) pozostaje W dodatnim związku z radzeniem sobie poprzez poszukiwanie kontaktów towarzyskich (PKT). U mężczyzn nie ujawnił się między tymi zmiennymi istotny związek. Okazało się także, że mężczyźni radzący sobie ze stresem za pomocą unikania (SSU), stosują również częściej styl skoncentrowany na emocjach (SSE). W grupie kobiet taka współzależność nie występuje.

Rozpatrując potwierdzenie zakładanych hipotez na poziomie grup, jedynie w grupie kobiet jedno z założeń nie znalazło potwierdzenia w wynikach, natomiast jeden ze związków okazał się mieć kierunek odwrotny do zakładanego. Sugeruje to, że w badanej grupie można wyróżnić odmienne wzorce radzenia sobie dla kobiet i mężczyzn. W celu podsumowania otrzymanych wyników poniżej zamieszczono tabelę zbiorczą (tabela 3) pokazującą rezultaty weryfikacji założonych hipotez w odniesieniu do całości badanej grupy oraz w podziale grupy ze względu na płeć.

Tabela 3. Rezultaty weryfikacji hipotez w odniesieniu do całości badanej grupy oraz w podziale grupy ze względu na płeć

\begin{tabular}{lccc}
\hline \multicolumn{1}{c}{ Zakładane hipotezy } & $\begin{array}{l}\text { Grupa bez po- } \\
\text { działu na płeć }\end{array}$ & Kobiety & Mężczyźni \\
\hline $\begin{array}{l}\text { H1: Istnieje pozytywny związek } \\
\text { między skalą SSZ a GSES }\end{array}$ & potwierdzona & potwierdzona & potwierdzona \\
$\begin{array}{l}\text { H2: Istnieje negatywny związek } \\
\text { między skalą SSE a GSES }\end{array}$ & potwierdzona & potwierdzona & potwierdzona \\
\hline
\end{tabular}




\section{H3: Istnieje negatywny związek między skalą SSU a GSES}

H4: Istnieje negatywny związek między skalą SSZ a PPS

H5: Istnieje pozytywny związek między skalą SSE a PPS

H6: Istnieje pozytywny związek międzypodskalą ACZ a PPS

H7: Istnieje pozytywny związek między kwestionariuszem SWC a skalą SSU

H8: Istnieje pozytywny związek między kwestionariuszem SWC a podskalą ACZ

Nazwy skal podano w tabeli 1.

W kolejnym kroku badania trafności teoretycznej testu CISS wykorzystano narzędzie własne (kwestionariusz SWC) obejmujące czynności zastępcze, które nie zostały ujęte na skali stylu skoncentrowanego na unikaniu (SSU). Celem takiego działania było sprawdzenie, czy uzasadnione jest uzupełnienie skali SSU o nowe itemy. Kwestionariusz SWC potraktowano jako rozszerzenie skali SSU. W celu zbadania czy takie działanie jest zasadne, wykonano analizę czynnikową na pozycjach testu CISS rozbudowanego o pozycje kwestionariusza SWC.

W celu określenia wewnętrznej struktury testu CISS rozszerzonego o pozycje kwestionariusza SWC, wykonano eksploracyjną analizę czynnikową metodą głównych składowych. Do ustalenia liczby czynników użyto kryterium wykresu osypiska, na podstawie którego stwierdzono, że należy wyodrębnić trzy czynniki. Zgodnie z otrzymanymi wynikami analizowano trzy czynniki, wyjaśniające $36 \%$ całkowitej wariancji, gdzie pierwszy czynnik wyjaśnia $14 \%$ wariancji, drugi czynnik - $11 \%$ wariancji i trzeci czynnik- $11 \%$ wariancji. Następnie wykonano analizę z rotacją ortogonalną czynników metodą Varimax.

W skład pierwszego czynnika weszło: 15 z 16 pozycji tworzących skalę SSE, dwie pozycje należące oryginalnie do skali SSU (pozycja 3 -,Myślę o czasach gdy było mi lepiej” i 44 -,,Robię sobie wolne, by uciec od problemu”), jedna pozycja należąca oryginalnie 
do skali SSZ (pozycja 39 - „Zmieniam kolejność spraw do załatwienia”) oraz jedna pozycja skali SWC („Korzystam z internetu szukając informacji, które pomogą mi poradzić sobie z sytuacją, w jakiej się znalazłem/łam”). Przyjmując za wartość kryterialną ładunek czynnikowy powyżej 0,30 należy wykluczyć ze skali pozycję kwestionariusza SWC.

Na drugi czynnik złożyło się 14 z 16 pozycji tworzących skalę SSU, jedna pozycja należąca oryginalnie do skali SSE (pozycja 7 - „Jestem skupiony(a) na swoich dolegliwościach fizycznych”) oraz cztery pozycje skali SWC (,Spędzam czas na portalach społecznościowych / komunikatorach”; „Uprawiam aktywność fizyczną, aby poczuć się lepiej”; „Korzystam z internetu, aby się oderwać na jakiś czas od mojego problemu”; „Piję alkohol lub stosuję inne środki, żeby poczuć się lepiej”). Powstałą skalę w dalszej części tekstu określa się jako $\mathrm{SSU}^{1}(\mathrm{SSU}+4$ pozycje SWC).

Trzeci czynnik utworzyło 15 z 16 pozycji skali SSZ oraz jedna pozycja skali SWC („Spędzam czas grając w gry, żeby o tym nie myśleć”), którą ze względu na ładunek czynnikowy poniżej 0,30 należy wykluczyć ze skali.

Podsumowując, analiza potwierdziła trójczynnikową strukturę testu, co jest zgodne z przewidywaniem otrzymania trzech głównych stylów radzenia sobie. Jedynie cztery z 48 pozycji kwestionariusza CISS zostały zakwalifikowane do innej skali niż ich oryginalne przypisanie, co w stosunku do długości skal jest niedużą nieprawidłowością. Należy również zaznaczyć, że otrzymana w analizie trójczynnikowa struktura testu stanowi argument na rzecz potwierdzenia trafności czynnikowej oraz teoretycznej kwestionariusza CISS.

Analizę struktury wewnętrznej testu przeprowadzono dla oryginalnych wersji skal kwestionariusza CISS oraz dla, otrzymanej w poprzedniej analizie, rozszerzonej wersji skali $\mathrm{SSU}^{1}$ (SSU+ 4 pozycje SWC). Takie działanie miało odpowiedzieć na pytanie, czy dodanie nowych pozycji do skali SSU poprawi charakterystykę psychometryczną skali pod względem zgodności wewnętrznej.

Spójność skal zbadano współczynnikiem $\alpha$-Cronbacha. Statystykę $\alpha$ obliczono oddzielnie dla skal: SSZ, SSE, SSU i SSU ${ }^{1}$. Wartości współczynnika $\alpha$-Cronbachadla skal wynoszą odpowiednio: SSZ - 0,84, SSE - 0,90, SSU - 0,86, SSU $^{1-0,86}$, co we wszystkich przypadkach należy uznać za bardzo dobry wynik, świadczący o wysokiej spójności każdej ze skal. Należy także podkreślić, że rozszerzenie skali SSU o nowe pozycje nie wpłynęło na podniesienie wartości współczynnika $\alpha$-Cronbacha. Wysokie wyniki wartości współczynników uzyskane w analizie struktury wewnętrznej testu dla każdej ze skal kwestionariusza CISS są kolejnym argumentem świadczącym na rzecz trafności teoretycznej badanego narzędzia. 
W celu oceny właściwości psychometrycznych poszczególnych pozycji kwestionariusza CISS przeanalizowano: moc dyskryminacyjną, wielkości ładunków czynnikowych oraz przynależność do skali każdej z pozycji.

Moc dyskryminacyjną obliczono na podstawie korelacji pozycji z przypisaną jej skalą (z wyłączeniem ze skali pozycji korelowanej). Za wartość krytyczną przyjęto za Szczepaniakiem, Strelauem i Wrześniewskim (1996) współczynnik korelacji o wartości 0,20. Za pomocą analizy czynnikowej (z rotacją varimax) pozycji ustalono ich ładunki czynnikowe. Ponownie, za Szczepaniakiem i in., za kryterium przyjęto wysokość ładunku czynnikowego o wartości minimum $0,30 \mathrm{z}$ własnym czynnikiem. Przynależność pozycji do skali oceniono na podstawie najwyższej wartości ładunku czynnikowego pozycji. Zestawienie wyników analizy pod kątem przedstawionych powyżej kryteriów zamieszczono w tabeli 4.

W odniesieniu do wartości ładunków czynnikowych jedynie dwie pozycje kwestionariusza nie spełniły przyjętego kryterium - pozycja skali SSU (pozycja 3 -,Myślę o czasach gdy było mi lepiej”) oraz pozycja skali SSZ (pozycja 39 - „Zmieniam kolejność spraw do załatwienia") uzyskały wartości ładunków czynnikowych poniżej 0,30 . W analizie czynnikowej oba te itemy zostały przypisane do skali SSE. Podobnie pozycja 44 (,Robię sobie wolne, by uciec od problemu") oryginalnie należąca do skali SSU, została przypisana do skali SSE, natomiast dwie pozycje skali SSE: pozycja 7 („Jestem skupiony(a) na swoich dolegliwościach fizycznych”) i pozycja 16 („Wmawiam sobie, że to w rzeczywistości nie dzieje się mnie") zostały przypisane do skali SSU. W odniesieniu do mocy dyskryminacyjnej tylko jedna pozycja (nr 39) nie spełniła założonego kryterium wielkości korelacji wynoszącego 0,20 .

Biorąc pod uwagę trzy przyjęte kryteria - moc dyskryminacyjną, przynależność pozycji do skali oraz wartość ładunku czynnikowego - należy stwierdzić, że pięć pozycji (nr 3,7, 16, 44 i 39) nie spełnia co najmniej jednego z założonych warunków. Przy czym pozycja nr 39 nie spełnia trzech z przyjętych założeń, pozycja nr 3 - dwóch, natomiast pozycje nr 7, 16 i 44 - nie spełniają jednego z założeń.

Należy podkreślić, że liczba pozycji wykazujących odstępstwa od przyjętych założeń jest niewielka w stosunku do długości skal kwestionariusza i usunięcie tych pozycji nie powoduje poprawy własności psychometrycznych narzędzia (rzetelność skal wzrasta od 0,004 do 0,015 wartości $\alpha$-Cronbacha). Na podstawie uzyskanych wyników można stwierdzić, że redukcja liczby pozycji nie jest zabiegiem koniecznym. Ponadto czynniki uzyskane w wyniku przeprowadzenia analizy czynnikowej, spójne z założonymi i otrzymanymi 


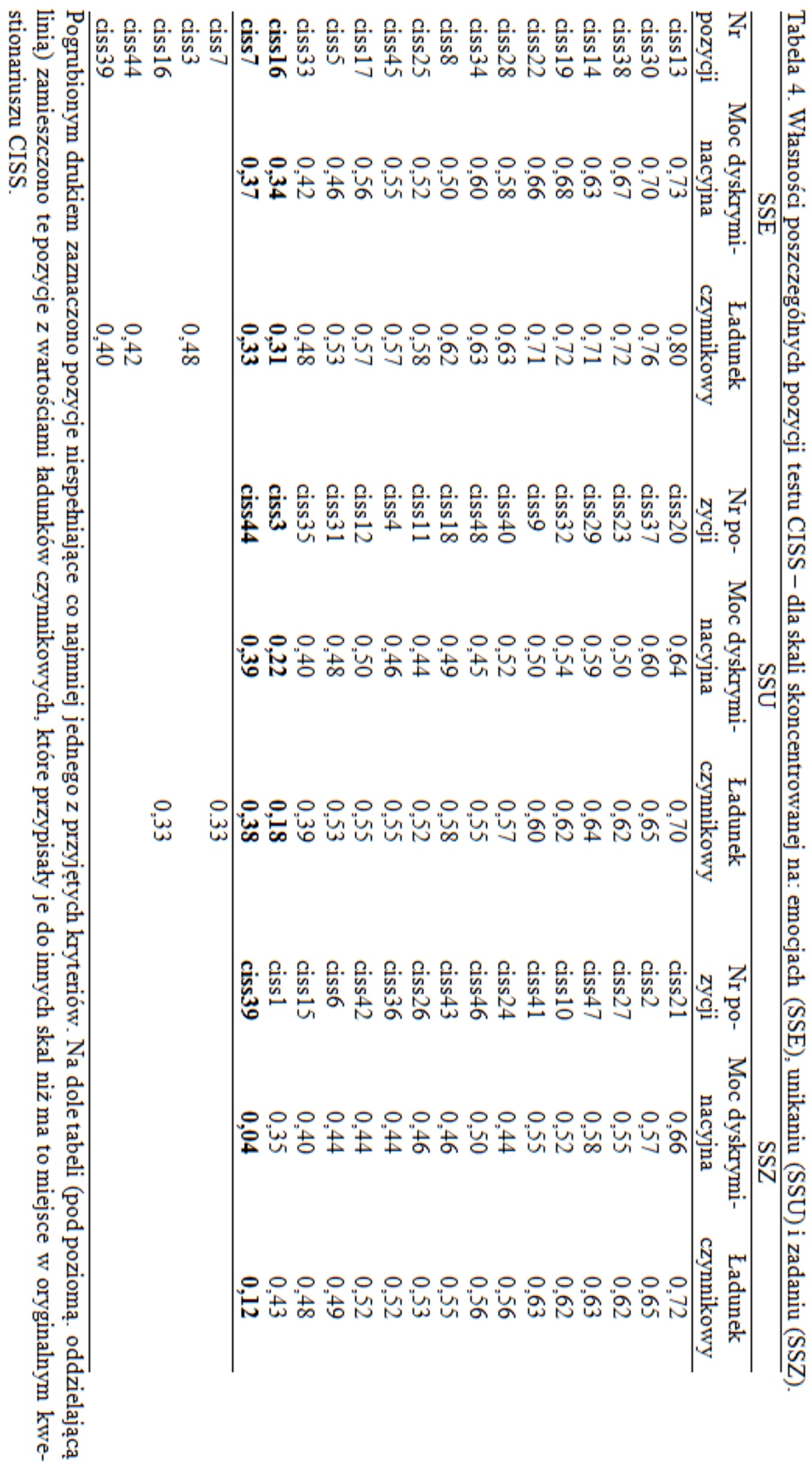


czynnikami u Endlera i Parkera (1990b, 1994), uzupełniają wnioski mówiące o trafności teoretycznej testu.

W kolejnym kroku analizy wyników, sprawdzono czy istnieją różnice w stosowanych stylach radzenia sobie ze stresem między kobietami a mężczyznami. W pierwszej kolejności zbadano kształt rozkładu wyników uzyskanych dla każdej ze skal i podskal kwestionariusza CISS, kwestionariusza SWC oraz skal GSES i PPS, osobno dla grupy kobiet i mężczyzn. Analiza testem Kołmogorowa-Smirnowa wykazała, że rozkład wyników, zarówno dla grupy kobiet $(n=76)$ jak i mężczyzn $(n=65)$ na skalach: SSZ, SSE, SSU, GSES, PPS, podskalach: ACZ i PKT oraz w kwestionariuszu SWC nie różni się istotnie od rozkładu normalnego. Wyniki analizy testem $t$-Studenta dla prób niezależnych przedstawiono w tabeli 5.

Tabela 5. Różnice między średnimi wynikami kobiet i mężczyzn na wymiarach: stylów radzenia sobie ze stresem, poczucia własnej skuteczności i tendencji do prokrastynacji.

\begin{tabular}{|c|c|c|c|c|c|c|c|}
\hline & \multicolumn{2}{|c|}{ Kobiety } & \multicolumn{2}{|c|}{ Mężczyźni } & \multirow[b]{2}{*}{$t$} & \multirow[b]{2}{*}{$d f$} & \multirow[b]{2}{*}{ Istotność } \\
\hline & $M$ & $S D$ & $M$ & $S D$ & & & \\
\hline SSZ & 58,49 & 8,16 & 58,74 & 8,28 & $-0,18$ & 139 & $p>0,05$ \\
\hline SSE & 50,26 & 10,50 & 41,12 & 11,52 & 4,92 & 139 & $p<0,001$ \\
\hline SSU & 49,92 & 9,66 & 39,77 & 10,09 & 6,10 & 139 & $p<0,001$ \\
\hline $\mathrm{ACZ}$ & 22,01 & 5,79 & 16,29 & 5,61 & 5,93 & 139 & $p<0,001$ \\
\hline PKT & 18,66 & 3,89 & 15,37 & 3,95 & 4,98 & 139 & $p<0,001$ \\
\hline SWC & 17,28 & 4,35 & 16,35 & 3,98 & 1,30 & 139 & $p>0,05$ \\
\hline GSES & 29,93 & 4,19 & 30,84 & 4,30 & $-1,27$ & 139 & $p>0,05$ \\
\hline PPS & 34,97 & 10,00 & 34,60 & 9,86 & 0,22 & 139 & $p>0,05$ \\
\hline
\end{tabular}

Nazwy skal podano w tabeli 1.

Analiza testem $t$-Studenta dla prób niezależnych wykazała istotne statystycznie różnice między kobietami a mężczyznami pod względem częstości stosowania stylu skoncentrowanego na: emocjach (SSE) i unikaniu (SSU). W sytuacjach stresowych kobiety częściej niż mężczyźni stosują wymienione style radzenia sobie. Na poziomie podskal wyniki wskazują także, że kobiety istotnie statystycznie częściej poszukują kontaktów towarzyskich oraz angażują się $\mathrm{w}$ czynności zastępcze. $\mathrm{Na}$ pozostałych badanych wymiarach nie zaobserwowano różnic między płciami. 


\section{Dyskusja i zakończenie}

Głównym celem prezentowanych badań było sprawdzenie czy obecnie kwestionariusz CISS nadal pozostaje trafnym teoretycznie narzędziem służącym do badania stylów radzenia sobie ze stresem. Praca szczególnie koncentrowała się na trafności teoretycznej jednej ze skal testu - skali skoncentrowanej na unikaniu (SSU). Badanie trafności kwestionariusza CISS metodą: analizy macierzy korelacji, analizy czynnikowej oraz analizy struktury wewnętrznej testu, dostarczyło argumentów świadczących na korzyść trafności teoretycznej, zarówno skali SSU jak i całego testu. W ramach przeprowadzonych analiz udało się także wskazać interesujące różnice $\mathrm{w}$ sposobach radzenia sobie ze stresem między badanymi kobietami i mężczyznami.

Otrzymane wyniki potwierdziły zdecydowaną większość zakładanych hipotez. Wobec czego zasadne jest stwierdzenie, że uzyskane dane dotyczące związku stylów radzenia sobie ze stresem z poczuciem własnej skuteczności, prokrastynacją oraz kwestionariuszem SWC, obejmującym czynności zastępcze nieujęte w CISS, dostarczają argumentów świadczących o trafności teoretycznej kwestionariusza CISS.

Analiza odpowiedzi osób badanych na pozycje narzędzia własnego - kwestionariusza SWC - ujawniła pewne sposoby radzenia sobie ze stresem, które nie były ujęte w CISS. Jednak rozszerzenie skali SSU o dodatkowe pozycje z kwestionariusza SWC, nie wpłynęło na poprawienie charakterystyki psychometrycznej skali pod względem zgodności wewnętrznej.

Analiza psychometryczna wszystkich pozycji kwestionariusza ujawniła pięć stwierdzeń wykazujących nieprawidłowości psychometryczne. Wyeliminowanie pozycji niespełniających wymaganych kryteriów nie wiązało się jednak z poprawą własności psychometrycznych narzędzia. Biorąc pod uwagę uzyskane dane i wyniki wcześniejszych badań w tym zakresie (Strelau, Jaworowska, Wrześniewski, Szczepaniak, 2005; Cosway, Endler, Sadler, Deary, 2000) wskazana byłaby modyfikacja lub zmiana przede wszystkim pozycji nr 3, 7, 16 i 39. Pozycje 32 oraz 35, których zmianę sugerowali Szczepaniak i in. (1996) uzyskały w niniejszym badaniu prawidłowe i zadawalające własności psychometryczne.

Analiza struktury wewnętrznej testu wykazała wysoką spójność każdej ze skal kwestionariusza CISS. Porównując otrzymane wyniki współczynników $\alpha$-Cronbacha do danych pochodzących z badań nad polską wersją narzędzia, można stwierdzić, że wartości otrzymanych współczynników są bardzo zbliżone do siebie (por. Strelau, Jaworowska, Wrześniewski, Szczepaniak, 2005). Przy czym w przypadku skali stylu skoncentrowanego na emo- 
cjach (SSE) oraz stylu skoncentrowanego na unikaniu (SSU) są one nieco wyższe od tych uzyskanych przez Strelaua i in. (2005).

Badanie potwierdziło związki między prokrastynacją a stylami radzenia sobie ze stresem uzyskane przez Fletta, Blanksteina i Martina (1995), dodatkowo wskazując na zróżnicowanie tych zależności ze względu na płeć. Uzyskane związki prokrastynacji ze stylami radzenia sobie ze stresem pomagają zrozumieć istotę radzenia sobie poprzez unikanie, którego nie należy utożsamiać z prokrastynacją, rozumianą jako irracjonalne odkładanie zadań. Między skalą SSU a zwlekaniem otrzymano słabą pozytywną korelację. Wynik ten pokazuje, że radzenie sobie skupione na unikaniu w niewielkim stopniu polega na destruktywnym zwlekaniu. Należy pamiętać, że prokrastynacja dotyczy wyłącznie działań, które jednostka ma zamiar podjąć, a radzenie sobie ze stresem poprzez unikanie obejmuje szerszy zakres sytuacji. Unikanie także niekoniecznie jest jednoznaczne z nieprzystosowawczym sposobem radzenia sobie. Potwierdzają to wyniki badań przemawiające za tym, że może ono pełnić adaptacyjną funkcję, gdy sytuacja nie podlega kontroli ze strony jednostki (Roth, Cohen, 1986), a także w krótkiej perspektywie czasu (Suls, Fletcher, 1985). Rozważając istotę stylu skoncentrowanego na unikaniu nasuwa się ponadto przypuszczenie, że w podskali poszukiwania kontaktów towarzyskich (PKT) zawarty jest komponent wsparcia społecznego. Potwierdzeniem tego może być, otrzymana przez Endlera i Parkera (1990b), umiarkowana korelacja między skalą SSU6 a skalą Poszukiwanie wsparcia społecznego kwestionariusza WCQ (Folkman, Lazarus, 1988). Endler i Parker definiują styl skupiony na unikaniu, jako polegający na wystrzeganiu się przeżywania emocji, myślenia oraz doświadczania trudnych, stresujących sytuacji (Strelau, Jaworowska, Wrześniewski, Szczepaniak, 2005). Jednym ze sposobów osiągnięcia tego celu ma być poszukiwanie kontaktów towarzyskich. Natomiast poszczególne pozycje podskali PKT, tj.,,Odwiedzam przyjaciela”, Spędzam czas z bliską osobą”, czy „Rozmawiam z kimś, kogo rady sobie cenię”, nie określają powodów tych zachowań. Wobec tego osoby, które korzystają z sieci wsparcia społecznego, aby otrzymać informacje, radę, praktyczną pomoc (tzw. wsparcie instrumentalne), a także wsparcie emocjonalne, twierdząco będą odpowiadać na pozycje podskali, przy czym ich celem nie będzie unikanie. Wykorzystywanie takich rodzajów wsparcia jak np. instrumentalnego czy poznawczego ma z pewnością więcej wspólnego $\mathrm{z}$ aktywnym podejmowaniem próby rozwiązania stresującej sytuacji. Warto o tym pamiętać

\footnotetext{
${ }^{6}$ Badania były przeprowadzane z zastosowaniem pierwotnej wersji kwestionariusza (MCI), gdzie w skali skoncentrowanej na unikaniu nie wyróżniano podskal.
} 
interpretując wyniki badań kwestionariuszem, tym bardziej, że powoli odchodzi się od uznawania za efektywne radzenie sobie, tylko procesów o charakterze indywidualnym (Greenglass, 2004).

Otrzymane wyniki sugerują występowanie istotnych różnic między kobietami i mężczyznami w strukturach radzenia sobie ze stresem. Uzyskane dane świadczące o tym, że kobiety częściej niż mężczyźni stosują styl skoncentrowany na emocjach (SSE) są spójne z polskimi i zagranicznymi doniesieniami (Endler, Parker, 1990b, 1994;Cosway, Endler, Sadler, Deary, 2000;Strelau, Jaworowska, Wrześniewski, Szczepaniak, 2005). Jeśli chodzi o otrzymany w badaniu wynik, mówiący o tym, że kobiety również częściej radzą sobie poprzez stosowanie stylu skoncentrowanego na unikaniu (SSU), sytuacja wygląda nieco inaczej. W polskich badaniach normalizacyjnych kwestionariusza CISS taki wynik uzyskano jedynie w najstarszej grupie wiekowej (Strelau i in., 2005). W dwóch pozostałych grupach nie zanotowano różnic w częstości stosowania stylu skupionego na unikaniu (SSU) między kobietami i mężczyznami. Ze względu na to, że różnice między płciami obserwowano tylko na jednej skali (SSE), podjęto decyzję o niewprowadzeniu zróżnicowania norm ze względu na płeć (Strelau i in., 2005). Natomiast w badaniach zagranicznych na przestrzeni lat replikuje się wynik świadczący o tym, że w sytuacjach stresujących kobiety częściej wykorzystują unikający styl radzenia sobie (Endler, Parker, 1990b, 1994;Cosway i in., 2000). Dane powyższego badania spójnie wpisują się w nurt badań zagranicznych. Oczywiście należy uwzględnić, że uzyskany wynik może mieć charakter incydentalny. Natomiast warto wziąć pod uwagę dość dużą ilość danych pochodzących z badań zagranicznych świadczących o tym, że styl skoncentrowany na unikaniu (SSU) jest bardziej charakterystyczny dla kobiet i ponownie przyjrzeć się tej kwestii w odniesieniu do polskiej adaptacji kwestionariusza. $\mathrm{Z}$ tego też względu wskazane byłoby przeprowadzenie stosownych badań na większą skalę, z uwzględnieniem różnych grup wiekowych. W przypadku replikacji wyniku uzyskanego w niniejszym badaniu, zasadne byłoby wprowadzenie zróżnicowania norm stenowych dla płci w polskiej adaptacji kwestionariusza CISS.

Im wyższe poczucie własnej skuteczności miały badane kobiety, tym chętniej angażowały się $\mathrm{w}$ poszukiwanie kontaktów towarzyskich. Te zachowania szły w parze $\mathrm{z}$ zadaniowym podejściem do problemu. Takie zależności nie ujawniły się $\mathrm{w}$ grupie mężczyzn. Na tej podstawie można wnosić, że stosowanie stylu skoncentrowanego na unikaniu u kobiet może mieć bardziej adaptacyjny charakter. W tym kontekście podkreśla się rozumienie radzenia sobie ze stresem przez poszukiwanie kontaktów towarzyskich jako korzystanie z sieci wsparcia społecznego. W świetle uzyskanych wyników sugeruje się rewi- 
zję rozumienia skali stylu skoncentrowanego na unikaniu, uwzględniając podskalę poszukiwania kontaktów towarzyskich w formie pozytywnego potencjału radzenia sobie.

Należy wspomnieć o ograniczeniach prezentowanego badania oraz ich wpływie na możliwość generalizacji wniosków. Badanie przeprowadzono na jednorodnej grupie studentów w wieku od 19 do 26 lat. Jest to grupa specyficzna ze względu na swój okres rozwojowy oraz podejmowane wówczas zadania, co może mieć związek ze sposobami radzenia sobie ze stresem. Celem zweryfikowania możliwości uogólnienia wniosków na populację polską, należałoby przeprowadzić kolejne badanie z udziałem różnych grup wiekowych. W tym celu warto by uwzględnić co najmniej trzy grupy, a także rozbudować listę pozycji kwestionariusza SWC. Kolejne pytania mogłyby uwzględniać czynności, tj. nadmierne angażowanie się w pracę czy gry hazardowe. Warto byłoby także umieścić pozycję o treści „Staram się zająć czymś innym”. Wydaje się to zasadne, jako że kwestionariusz CISS podaje osiem czynności zastępczych, co z pewnością nie wyczerpuje sposobów unikania myślenia, odczuwania czy doświadczania stresujących sytuacji.

Prezentowana praca stanowi wkład w weryfikację trafności polskiej wersji kwestionariusza CISS. Wnioski z niej płynące upoważniają do stwierdzenia, że narzędzie nadal wykazuje satysfakcjonującą trafność teoretyczną. Nie powinno to jednak stanowić przeszkody przed dalszą pracą nad udoskonaleniem kwestionariusza i jego rozwijaniem.

\section{Literatura cytowana}

Bandura, A. (1991). Self-Regulation of Motivation Through Anticipatory and Self-Reactive Mechanisms.W: R. A. Dienstbier, (red.), Perspectives on motivation:Nebraska Symposium on Motivation.(s. 69-164). Lincoln: University of Nebraska Press.

Bandura, A. (1993). Perceived Self-Efficacy in Cognitive Development and Functioning. Educational Psychologist, 28(2), 117-148. DOI:10.1207/s15326985ep2802_3.

Bandura, A. (2001). Social Cognitive Theory: An Agentic Perspective. Annual Review of Psychology, 52, 1-26. DOI:10.1146/annurev.psych.52.1.1.

Cosway, R., Endler, N. S., Sadler, A. J., Deary, I. J. (2000). The Coping Inventory for Stressful Situations: Factorial Structure and Associations With Personality Traits and Psychological Health. Journal of Applied Biobehavioral Research, 5(2), 121-143. DOI:10.1111/j.1751 9861.2000.tb00069.x.

Endler, N. S., Parker, J. D. (1990a). Coping Inventory for Stressful Situations (CISS): Manual. Toronto: Multi-Health Systems, Inc. 
Endler, N. S., Parker, J. D. (1990b). Multidimensional assessment of coping: A critical evaluation. Journal of Personality and Social Psychology, 58(5), 844-854. DOI:10.1037//00223514.58.5.844.

Endler, N. S., Parker, J. D. (1994). Assessment of multidimensional coping: Task, emotion, and avoidance strategies. Psychological Assessment, 6(1), 50.

Flett, G. L., Blankstein, K. R., Martin, T. R. (1995). Procrastination, Negative Self-Evaluation, and Stress in Depression and Anxiety. W:J. R. Ferrari, J. L. Johnson, W. G. McCown (red.), Procrastination and Task Avoidance: Theory, Research, and Treatment. (s. 137-166). New York: Plenum Press.

Folkman, S., Lazarus, R. S. (1988).Ways of coping questionnaire: Sampler set: manual, test booklet, scoring key. PaloAlto: Consulting Psychologists Press.

Greenglass, E. (2004). Różnice wynikające z ról płciowych, wsparcie społeczne i radzenie sobie ze stresem. W: R. Cieślak, H. Sęk, (red.), Wsparcie społeczne, stres $i$ zdrowie. (s. 146-149). Warszawa: Wydawnictwo Naukowe PWN.

Heszen, I., (2013). Psychologia stresu: Korzystne i niekorzystne skutki stresu życiowego. Warszawa: Wydawnictwo Naukowe PWN.

Juczyński, Z. (2009). Narzędzia pomiaru w promocji i psychologii zdrowia. Warszawa: Pracownia Testów Psychologicznych.

Klein, E. (1966). A comprehensive etymological dictionary of the English language: Dealing with the origin of words and their sense development thus illustrating the history of civilization and culture. Amsterdam: Elsevier.

Lay, C. (1986). At last, my research article on procrastination. Journal of Research in Personality, 20 (4), 474-495. doi:10.1016/0092-6566(86)90127-3

Oleś, P. (2003). Wprowadzenie do psychologii osobowości. Warszawa: Wydawnictwo Naukowe "Scholar".

Roth, S., Cohen, L. J. (1986).Approach, avoidance, and coping with stress. American Psychologist, 41(7), 813-819. DOI:10.1037//0003-066X.41.7.813.

Shikai N., Uji M., Chen Z., Hiramura H., Tanaka N., Shono M., Kitamura T. (2007). The Role of Coping Styles and Self-efficacy in the Development of Dysphoric Mood Among Nursing Students. Journal of Psychopathology and Behavioral Assessment, 29,241-248. DOI:10.1007/s10862-007-9043-3.

Steel, P. (2007).The Nature of Procrastination: A Meta-Analytic and Theoretical Review of Quintessential Self-Regulatory Failure. Psychological Bulletin, 133(1), 65-94. DOI:10.1037/00332909.133.1.65.

Steel, P. (2010). Arousal, avoidant and decisional procrastinators: Do they exist? Personality and Individual Differences, 48 (8), 926-934. DOI:10.1016/j.paid.2010.02.025.

Strelau, J., Jaworowska, A., Wrześniewski, K., Szczepaniak, P. (2005). Kwestionariusz Radzenia Sobie w Sytuacjach Stresowych CISS: Podręcznik do polskiej normalizacji. Warszawa: Pracownia Testów Psychologicznych Polskiego Towarzystwa Psychologicznego. 
Suls, J., Fletcher, B. (1985). The Relative Efficacy of Avoidant and Nonavoidant Coping Strategies: A Meta-Analysis. Health Psychology, 4(3), 249-288. DOI:10.1037/0278- 6133.4.3.249.

Szczepaniak, P., Strelau, J., Wrześniewski, K. (1996). Diagnoza stylów radzenia sobie ze stresem za pomocą polskiej wersji kwestionariusza CISS Endlera i Parkera. Przegląd Psychologiczny, $39(1), 187-210$. 